\title{
CRYSTAL STRUCTURE OF (E)-N'-((1H-PYRROL-2-YL)METHYLENE)-4-HYDROXYBENZOHYDRAZIDE
}

\section{GHODRAT MAHMOUDI ${ }^{a, *}$, SADEGH ROSTAMNIA ${ }^{a}$, GUILLERMO ZARAGOZA $^{b}$, IVÁN BRITO $^{c}$, JONATHAN CISTERNA ${ }^{c} A N D$ ALEJANDRO CÁRDENAS ${ }^{d}$}

\author{
${ }^{a}$ Department of Chemistry, Faculty of Science, University of Maragheh, P.O. Box 55181-83111, Maragheh, Iran \\ ${ }^{b}$ Unidad de RX, Edificio CACTUS, Campus Vida, Santiago Compostela, 15782, Spain \\ ${ }^{c}$ Departamento de Quimica, Universidad de Antofagasta, Avda. Universidad de Antofagasta 02800, Campus Coloso \\ Antofagasta-Chile, Antofagasta 1240000, Chile, \\ ${ }^{d}$ Departamento de Física, Universidad de Antofagasta, Avda. Universidad de Antofagasta 02800, Campus Coloso Antofagasta-Chile,
} Antofagasta 1240000, Chile,

\begin{abstract}
The title compound corresponds to an enaminone $E$ isomer in the solid state. X-ray structure shows that this crystallizes in the orthorrombic system, with space group Pna2 $2_{1}$ with 2 independent molecules in the asymmetric unit in a non-centrosymmetric setting. The CNNC unit forms dihedral angles of 5.9(3)/2.1(3); 19.7(3)/17.6(3) ${ }^{\circ}$ with the pyrrole and phenol rings for molecules A and B respectively. The main differences between both molecules is the dihedral torsion between rings, their mean planes form dihedral angles of $25.45(15)$ and $15.38(15)^{\circ}$ for the molecules A and $\mathrm{B}$. In the asymmetric unit, molecules are linked by two weak $\mathrm{N}-$ $\mathrm{H} \cdots \mathrm{O}$ hydrogen bonds with set graph-motif $R_{2}^{2}(16)$. The crystal structure of title compound generates a two dimensional supramolecular network lying parallel (110) with hydrogen bonds interactions between $\mathrm{O}-\mathrm{H} \cdots \mathrm{O}$ and $\mathrm{N}-\mathrm{H} \cdots \mathrm{O}$ along to [100] and [001] direction with graph set motifs $R_{1}^{2}(5), R_{2}^{2}(10), C_{1}^{1}(8)$ and $C_{1}^{1}(12)$. $\pi$ $\pi$ stacking interactions are not observed. Hirshfeld surface analysis were used to verify the contributions of the different intermolecular interactions. Both molecules are essentially overlaid between them with $\mathrm{RMSD}=0.0574$; $\max \mathrm{D}=0.1211 \AA ̊$ considering inversion and flexibility.
\end{abstract}

Keywords: Hydrazide, X-ray diffracction, non-covalent interactions, Hirshfeld surface, energy framework.

\section{INTRODUCTION} picosagen bonds were extensively used in the synthesis, catalysis, crystal engineering, drug delivery, etc. ${ }^{1-11}$. Among those, hydrogen bonding has turned out to be particularly suitable for design of organic and coordination compounds $^{12-19}$. Herein, we found strong intermolecular hydrogen bonds in (E)-N'-((1H-pyrrol-2-yl)methylene)-4-hydroxybenzohydrazide (I) and other weak non-covalent interactions, which were analized by Hirshfeld surface analysis to observe all contributions of the different intermolecular interactions stabilizing final 2D organic framework network (Scheme 1).<smiles>O=C(N/N=C/c1ccc[nH]1)c1ccc(O)cc1</smiles>

(I)<smiles>O/C(=N\N=C\c1ccc[nH]1)c1ccc(O)cc1</smiles>

(II)

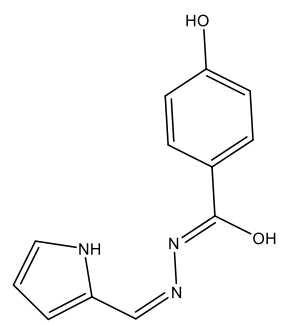

(III)
Scheme 1.

\section{EXPERIMENTAL}

High purity (E)- $N$ '-((1H-pyrrol-2-yl)methylene)-4-hydroxybenzohydrazide was prepared in the laboratory following the literature $\operatorname{method}^{20}$. A possible future solution to our inability to grow single-crystals is the use of very interesting and unusual glassware for reaction/crystallization apparatus (branched tube) recently developed by us ${ }^{21}$. For the molecular structure of title compound, $\mathrm{H}$ atoms were located in the difference Fourier map and refined freely with distances in the range of 0.88(4) - 0.99(3) $\AA$, except for the atoms H5A and $\mathrm{H} 3 \mathrm{~B}$, which were treated has riding model, with distances $\mathrm{C} 5 \mathrm{~A}-\mathrm{H} 5 \mathrm{~A}$ and N3B-H3B of 0.951 and $0.88 \AA$ and $\mathrm{U}_{\text {iso }}(\mathrm{H})$ fixed at $1.2 \mathrm{U}_{\text {eq }}$ of the parent $\mathrm{C}$ and $\mathrm{N}$ atoms respectively.

X-ray diffraction patterns of title compound were collected using a Bruker SMART APEX-II CCD area detector equipped with graphite-monochromated
Weak interactions, such as hydrogen, halogen, chalcogen, pnicogen, tetrel and

Mo-K $\alpha$ radiation $(\lambda=0.71073 \AA)$ at $100 \mathrm{~K}$. The diffraction frames were integrated using the APEX3 package ${ }^{22}$. The structure of were solved by intrinsic phasing ${ }^{23}$ using the OLEX 2 program ${ }^{24}$. The structure was then refined with fullmatrix least-square methods based on $F^{2}(\text { SHELXL-2014) })^{23}$. For (I), nonhydrogen atoms were refined with anisotropic displacement parameters. A summary of the details about crystal data, collection parameters and refinement are documented in Table 1, and additional crystallographic details are in the CIF files. ORTEP views were drawn using OLEX2 software ${ }^{24}$. CCDC 1917875 contain the supplementary crystallographic data for this paper. These data can be obtained free of charge from the Cambridge Crystallographic Data Centre via www.ccdc.cam.as.uk/data_request/cif.

Table 1. Crystal data parameters for compound (I)

\begin{tabular}{|l|l|}
\hline Empirical Formula & $\mathrm{C}_{12} \mathrm{H}_{11} \mathrm{~N}_{3} \mathrm{O}_{2}$ \\
\hline Formula mass, $\mathrm{g} \mathrm{mol}^{-1}$ & 229.24 \\
\hline Collection $\mathrm{T}, \mathrm{K}$ & 99.99 \\
\hline crystal system & orthorhombic \\
\hline space group & $\mathrm{Pna}_{1}$ \\
\hline$a(\AA)$ & $15.3668(9)$ \\
\hline$b(\AA)$ & $11.0969(8)$ \\
\hline$c(\AA)$ & $12.7075(10)$ \\
\hline$\alpha, \beta, \gamma\left({ }^{\circ}\right)$ & 90 \\
\hline$V\left(\AA^{3}\right)$ & $2166.9(3)$ \\
\hline$Z$ & 8 \\
\hline$\rho_{\text {calcd }}\left(\mathrm{gcm}{ }^{-3}\right)$ & 1.405 \\
\hline Crystal size $(\mathrm{mm})$ & $0.29 \times 0.21 \times 0.14$ \\
\hline$F(000)$ & 960.0 \\
\hline abs coeff $\left(\mathrm{mm}{ }^{-1}\right)$ & 0.099 \\
\hline $2 \theta$ range $\left({ }^{\circ}\right)$ & 4.528 to 52.024 \\
\hline range h,k,1 & $-17 / 18,-13 / 13,-15 / 15$ \\
\hline No. total refl. & 4264 \\
\hline No. unique refl. & 4264 \\
\hline Comp. $\theta_{\max }(\%)$ & $1.00 / 26.00$ \\
\hline Max/min transmission & $0.943,1.000$ \\
\hline Data/Restraints/Parameters & $4264 / 1 / 387$ \\
\hline Final R $[I>2 \sigma(I)]$ & $\mathrm{R}_{1}=0.0368, \mathrm{wR}_{2}=0.0820$ \\
\hline $\mathrm{R}$ indices $($ all data) & $\mathrm{R}_{1}=0.0529, \mathrm{wR}_{2}=0.0907$ \\
\hline Goodness of fit / $\mathrm{F}^{2}$ & 1.038 \\
\hline Largest diff. Peak/hole $\left(\mathrm{e} \AA^{-3}\right)$ & $0.18 /-0.24$ \\
\hline & \\
\hline
\end{tabular}




\section{RESULTS AND DISCUSSIONS}

The title compound corresponds to an enaminone $E$ isomer in the solid state. The crystal structure can be described in terms of discrete molecules with two independent molecules in the asymmetric unit. An analysis of normal probability plot $^{25}$ indicates that differences in the bond lengths and angles of these molecules are statistically insignificant. The average values will therefore be discussed. The sum of the angles around the N1 and N3 atoms [358.9 (3); 359.7(3) ${ }^{\circ}$ reflects a planar $s p 2$ geometry. All the distances and angles are normal ${ }^{26,27}$ and comparable with similar compounds, refcode JOVQUI ${ }^{28}$ and VETPAO ${ }^{29}$, included in CCDC data base ${ }^{30}$. The CNNC unit forms dihedral angles of 5.9(3)/2.1(3) 19.7(3)/17.6(3) $)^{\circ}$ with the pyrrole and phenol rings for molecules A and B respectively. The main differences between both molecules is the dihedral torsion between rings, their mean planes form dihedral angles of 25.45(15) and $15.38(15)^{\circ}$ for the molecules $\mathrm{A}$ and $\mathrm{B}$. In the asymmetric unit, molecules are linked by two weak $\mathrm{N}-\mathrm{H} \cdots \mathrm{O}$ hydrogen bonds with set graph-motif $R_{2}^{2}(16)$. The crystal structure of title compound generates a two dimensional supramolecular network lying parallel (110) with hydrogen bonds interactions between $\mathrm{O}$ $\mathrm{H} \cdots \mathrm{O}$ and $\mathrm{N}-\mathrm{H} \cdots \mathrm{O}$ along to [100] and [001] direction with graph set motifs $R_{1}^{2}(5), R_{2}^{2}(10), C_{1}^{1}(8)$ and $C_{1}^{1}(12) . \pi-\pi$ stacking interactions are not observed. Both molecules are essentially overlaid between them with RMSD $=0.0574$; $\max$ $\mathrm{D}=0.1211 \AA$ $\mathrm{considering} \mathrm{inversion} \mathrm{and} \mathrm{flexibility.}$

The molecular structure shows average dihedral angles of $20.1(4)^{\circ}$ and $16.0(4)^{\circ}$ between 4-hidroxyphenyl ring and $-\mathrm{C}(\mathrm{O})-\mathrm{NH}-$ moiety and, $3.90(4)^{\circ}$ between pyrrole ring and $\mathrm{N} 2$ atoms, $4.50(4)^{\circ}$, between carbonyl and $-\mathrm{NH}-\mathrm{N}=$ fragment, respectively.

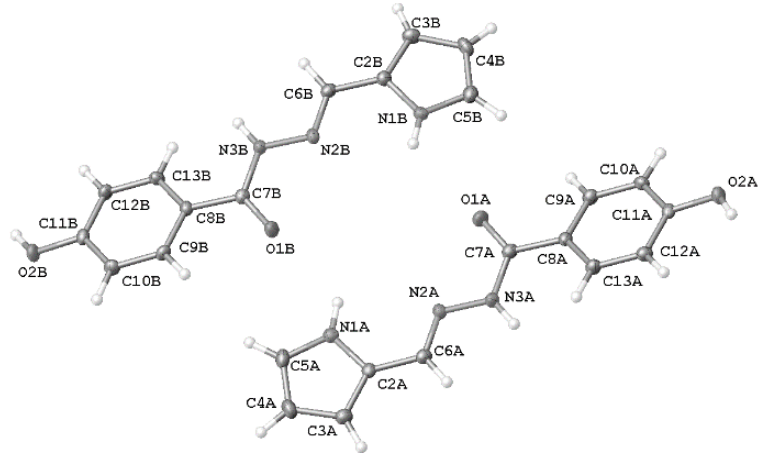

Figure 1. ORTEP plot of the title compound. Thermal ellipsoids were drawn with $30 \%$ of probability.

Half-normal probability plot analysis was used to (i) investigate the reliability of the s.u.'s and (ii) identify systematic geometrical differences in two molecules. A comparison of the bond distances and angles of the fitted residues, reveals that the two molecules do not show any significant geometrical differences (see Table $2)^{31}$. The slope plot of the bond angles is 0.4910 and the intercept is -0.0016 , showed a straight line with an intercept of almost zero and a slope of less than unity indicating that the s.u.s are slightly overestimated. The largest difference $\left(-0.80^{\circ}\right)$ is between the $\mathrm{C} 8 \mathrm{~A}-\mathrm{C} 9 \mathrm{~A}-\mathrm{C} 10 \mathrm{~A}$ angle in the first molecule and C8B -C9B -C10B in the second molecule, with Diff/Sig of -1.89, (RMS Angle Fit $=0.336^{\circ}$, sample size of 23$)^{32}$.

Table 2. Bond distances and angles of the title compound.

\begin{tabular}{|c|c|c|c|c|c|c|c|c|c|c|c|c|c|}
\hline \multicolumn{2}{|c|}{ Atom } & \multirow{2}{*}{$\begin{array}{c}\text { Length/Å } \\
1.238(4)\end{array}$} & \multicolumn{2}{|c|}{ Atom } & \multirow{2}{*}{$\begin{array}{c}\text { Length/Å } \\
1.236(4)\end{array}$} & \multicolumn{3}{|c|}{ Atom } & \multirow{2}{*}{$\begin{array}{l}\text { Angle }^{\circ} \\
109.0(3)\end{array}$} & \multicolumn{3}{|c|}{ Atom } & \multirow{2}{*}{$\begin{array}{l}\text { Angle }^{\circ} \\
109.2(3)\end{array}$} \\
\hline $\mathrm{O} 1 \mathrm{~A}$ & C7A & & O1B & $\mathrm{C} 7 \mathrm{~B}$ & & $\mathrm{C} 5 \mathrm{~A}$ & $\mathrm{~N} 1 \mathrm{~A}$ & $\mathrm{C} 2 \mathrm{~A}$ & & C5B & $\mathrm{N} 1 \mathrm{~B}$ & $\mathrm{C} 2 \mathrm{~B}$ & \\
\hline $\mathrm{O} 2 \mathrm{~A}$ & $\mathrm{C} 11 \mathrm{~A}$ & $1.360(4)$ & $\mathrm{O} 2 \mathrm{~B}$ & C11B & $1.357(4)$ & C6A & $\mathrm{N} 2 \mathrm{~A}$ & $\mathrm{~N} 3 \mathrm{~A}$ & $116.0(3)$ & C6B & $\mathrm{N} 2 \mathrm{~B}$ & N3B & $116.5(3)$ \\
\hline $\mathrm{N} 1 \mathrm{~A}$ & $\mathrm{C} 2 \mathrm{~A}$ & $1.373(5)$ & N1B & $\mathrm{C} 2 \mathrm{~B}$ & $1.373(5)$ & $\mathrm{C} 7 \mathrm{~A}$ & $\mathrm{~N} 3 \mathrm{~A}$ & $\mathrm{~N} 2 \mathrm{~A}$ & $118.5(3)$ & $\mathrm{C} 7 \mathrm{~B}$ & $\mathrm{~N} 3 \mathrm{~B}$ & $\mathrm{~N} 2 \mathrm{~B}$ & $118.0(2)$ \\
\hline $\mathrm{N} 1 \mathrm{~A}$ & C5A & $1.363(4)$ & N1B & $\mathrm{C} 5 \mathrm{~B}$ & $1.362(4)$ & N1A & $\mathrm{C} 2 \mathrm{~A}$ & $\mathrm{C} 3 \mathrm{~A}$ & $107.9(3)$ & N1B & $\mathrm{C} 2 \mathrm{~B}$ & $\mathrm{C} 3 \mathrm{~B}$ & $107.4(3)$ \\
\hline $\mathrm{N} 2 \mathrm{~A}$ & N3A & $1.380(4)$ & $\mathrm{N} 2 \mathrm{~B}$ & $\mathrm{~N} 3 \mathrm{~B}$ & $1.379(3)$ & N1A & $\mathrm{C} 2 \mathrm{~A}$ & C6A & $122.6(3)$ & N1B & $\mathrm{C} 2 \mathrm{~B}$ & $\mathrm{C} 6 \mathrm{~B}$ & $122.4(3)$ \\
\hline $\mathrm{N} 2 \mathrm{~A}$ & C6A & $1.278(4)$ & $\mathrm{N} 2 \mathrm{~B}$ & $\mathrm{C} 6 \mathrm{~B}$ & $1.278(4)$ & $\mathrm{C} 3 \mathrm{~A}$ & $\mathrm{C} 2 \mathrm{~A}$ & C6A & $129.4(3)$ & $\mathrm{C} 3 \mathrm{~B}$ & $\mathrm{C} 2 \mathrm{~B}$ & $\mathrm{C} 6 \mathrm{~B}$ & $129.6(3)$ \\
\hline $\mathrm{N} 3 \mathrm{~A}$ & C7A & $1.353(5)$ & $\mathrm{N} 3 \mathrm{~B}$ & $\mathrm{C} 7 \mathrm{~B}$ & $1.356(4)$ & $\mathrm{C} 2 \mathrm{~A}$ & $\mathrm{C} 3 \mathrm{~A}$ & $\mathrm{C} 4 \mathrm{~A}$ & $107.2(3)$ & $\mathrm{C} 2 \mathrm{~B}$ & $\mathrm{C} 3 \mathrm{~B}$ & $\mathrm{C} 4 \mathrm{~B}$ & $107.2(3)$ \\
\hline $\mathrm{C} 2 \mathrm{~A}$ & $\mathrm{C} 3 \mathrm{~A}$ & $1.378(5)$ & $\mathrm{C} 2 \mathrm{~B}$ & $\mathrm{C} 3 \mathrm{~B}$ & $1.383(5)$ & $\mathrm{C} 5 \mathrm{~A}$ & $\mathrm{C} 4 \mathrm{~A}$ & $\mathrm{C} 3 \mathrm{~A}$ & $107.6(3)$ & $\mathrm{C} 5 \mathrm{~B}$ & $\mathrm{C} 4 \mathrm{~B}$ & $\mathrm{C} 3 \mathrm{~B}$ & $108.0(3)$ \\
\hline $\mathrm{C} 2 \mathrm{~A}$ & C6A & $1.440(5)$ & $\mathrm{C} 2 \mathrm{~B}$ & $\mathrm{C} 6 \mathrm{~B}$ & $1.441(5)$ & N1A & $\mathrm{C} 5 \mathrm{~A}$ & $\mathrm{C} 4 \mathrm{~A}$ & $108.3(3)$ & $\mathrm{C} 4 \mathrm{~B}$ & $\mathrm{C} 5 \mathrm{~B}$ & N1B & $108.2(3)$ \\
\hline $\mathrm{C} 3 \mathrm{~A}$ & $\mathrm{C} 4 \mathrm{~A}$ & $1.406(5)$ & $\mathrm{C} 3 \mathrm{~B}$ & $\mathrm{C} 4 \mathrm{~B}$ & $1.401(5)$ & $\mathrm{N} 2 \mathrm{~A}$ & C6A & $\mathrm{C} 2 \mathrm{~A}$ & $119.6(3)$ & $\mathrm{N} 2 \mathrm{~B}$ & C6B & $\mathrm{C} 2 \mathrm{~B}$ & $119.3(3)$ \\
\hline $\mathrm{C} 4 \mathrm{~A}$ & C5A & $1.369(5)$ & $\mathrm{C} 4 \mathrm{~B}$ & $\mathrm{C} 5 \mathrm{~B}$ & $1.362(5)$ & O1A & C7A & $\mathrm{N} 3 \mathrm{~A}$ & 121.3(3) & O1B & C7B & N3B & $121.4(3)$ \\
\hline C7A & $\mathrm{C} 8 \mathrm{~A}$ & $1.482(5)$ & $\mathrm{C} 7 \mathrm{~B}$ & $\mathrm{C} 8 \mathrm{~B}$ & $1.487(5)$ & O1A & C7A & $\mathrm{C} 8 \mathrm{~A}$ & $122.3(3)$ & O1B & $\mathrm{C} 7 \mathrm{~B}$ & $\mathrm{C} 8 \mathrm{~B}$ & 122.1(3) \\
\hline $\mathrm{C} 8 \mathrm{~A}$ & C9A & $1.393(5)$ & $\mathrm{C} 8 \mathrm{~B}$ & $\mathrm{C} 9 \mathrm{~B}$ & $1.388(5)$ & $\mathrm{N} 3 \mathrm{~A}$ & C7A & $\mathrm{C} 8 \mathrm{~A}$ & 116.4(3) & $\mathrm{N} 3 \mathrm{~B}$ & $\mathrm{C} 7 \mathrm{~B}$ & $\mathrm{C} 8 \mathrm{~B}$ & $116.4(3)$ \\
\hline $\mathrm{C} 8 \mathrm{~A}$ & $\mathrm{C} 13 \mathrm{~A}$ & $1.401(4)$ & $\mathrm{C} 8 \mathrm{~B}$ & C13B & $1.397(4)$ & C9A & C8A & $\mathrm{C} 7 \mathrm{~A}$ & $118.6(3)$ & $\mathrm{C} 9 \mathrm{~B}$ & $\mathrm{C} 8 \mathrm{~B}$ & $\mathrm{C} 7 \mathrm{~B}$ & $118.5(3)$ \\
\hline $\mathrm{C} 9 \mathrm{~A}$ & $\mathrm{C} 10 \mathrm{~A}$ & $1.384(4)$ & $\mathrm{C} 9 \mathrm{~B}$ & C10B & $1.383(5)$ & C9A & $\mathrm{C} 8 \mathrm{~A}$ & $\mathrm{C} 13 \mathrm{~A}$ & $118.9(3)$ & $\mathrm{C} 9 \mathrm{~B}$ & $\mathrm{C} 8 \mathrm{~B}$ & C13B & $118.6(3)$ \\
\hline C10A & $\mathrm{C} 11 \mathrm{~A}$ & $1.394(4)$ & C10B & C11B & $1.397(4)$ & C13A & C8A & C7A & $122.5(3)$ & C13B & $\mathrm{C} 8 \mathrm{~B}$ & $\mathrm{C} 7 \mathrm{~B}$ & $122.9(3)$ \\
\hline C11A & $\mathrm{C} 12 \mathrm{~A}$ & $1.392(5)$ & C11B & C12B & $1.390(5)$ & C10A & C9A & $\mathrm{C} 8 \mathrm{~A}$ & $120.5(3)$ & C10B & $\mathrm{C} 9 \mathrm{~B}$ & $\mathrm{C} 8 \mathrm{~B}$ & 121.3(3) \\
\hline $\mathrm{C} 12 \mathrm{~A}$ & $\mathrm{C} 13 \mathrm{~A}$ & $1.380(5)$ & C12B & C13B & $1.384(5)$ & C9A & $\mathrm{C} 10 \mathrm{~A}$ & C11A & $120.0(3)$ & $\mathrm{C} 9 \mathrm{~B}$ & $\mathrm{C} 10 \mathrm{~B}$ & C11B & $119.5(3)$ \\
\hline & & & & & & $\mathrm{O} 2 \mathrm{~A}$ & C11A & C10A & $117.8(3)$ & $\mathrm{O} 2 \mathrm{~B}$ & C11B & C10B & $117.6(3)$ \\
\hline & & & & & & $\mathrm{O} 2 \mathrm{~A}$ & C11A & $\mathrm{C} 12 \mathrm{~A}$ & $122.3(3)$ & $\mathrm{O} 2 \mathrm{~B}$ & C11B & C12B & $122.6(3)$ \\
\hline & & & & & & $\mathrm{C} 12 \mathrm{~A}$ & C11A & C10A & $120.0(3)$ & $\mathrm{C} 12 \mathrm{~B}$ & C11B & C10B & $119.8(3)$ \\
\hline & & & & & & $\mathrm{C} 13 \mathrm{~A}$ & $\mathrm{C} 12 \mathrm{~A}$ & C11A & $119.8(3)$ & C13B & C12B & C11B & $119.9(3)$ \\
\hline & & & & & & $\mathrm{C} 12 \mathrm{~A}$ & C13A & $\mathrm{C} 8 \mathrm{~A}$ & $120.8(3)$ & C12B & C13B & $\mathrm{C} 8 \mathrm{~B}$ & $120.8(3)$ \\
\hline
\end{tabular}


The crystal structure of title compound generates a two dimensional supramolecular network with hydrogen bonds interactions between $\mathrm{O}-\mathrm{H} \cdots \mathrm{O}$ and $\mathrm{N}-\mathrm{H} \cdots \mathrm{O}$ along to [100] and [001] direction with graph set motifs ${ }^{33}$ visible $R_{1}^{2}(5), R_{2}^{2}(10), C_{1}^{1}(8)$ and $C_{1}^{1}(12)$ (see Figure 2 and Table 3 ).
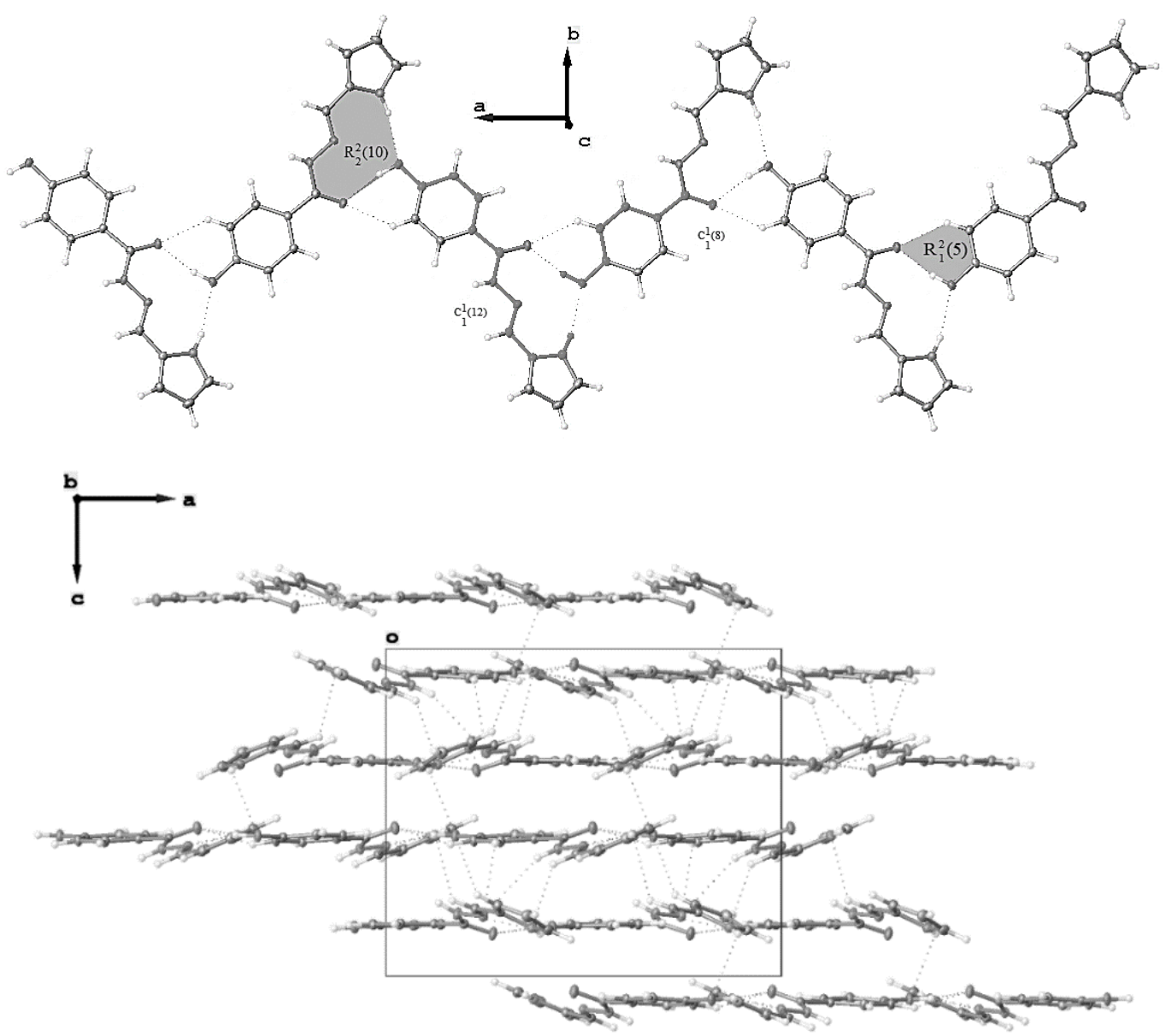

Figure 2. Crystal packing of the title compound showing graph set motifs (top) and intermolecular hydrogen bond between neighbor molecules (bottom).

Table 3 Hydrogen Bonds Interactions for title compound.

\begin{tabular}{|c|c|c|c|c|c|c|}
\hline D & $\mathbf{H}$ & $\mathbf{A}$ & $\mathbf{d}(\mathbf{D}-\mathbf{H}) / \AA$ & $\mathbf{d}(\mathbf{H}-\mathbf{A}) / \AA$ & $\mathbf{d}(\mathbf{D}-\mathbf{A}) / \AA$ & D-H-A/ ${ }^{\circ}$ \\
\hline $\mathrm{O} 2 \mathrm{~A}$ & $\mathrm{H} 2 \mathrm{~A}$ & $\mathrm{O}_{1} \mathrm{~A}^{1}$ & $0.88(4)$ & $1.95(4)$ & $2.819(3)$ & $168(4)$ \\
\hline N1A & H1A & $\mathrm{O} 2 \mathrm{~A}^{2}$ & $0.90(4)$ & $2.25(4)$ & $3.097(4)$ & $156(4)$ \\
\hline C6A & H6A & $\mathrm{N}^{1} \mathrm{~B}^{3}$ & $0.97(3)$ & $2.73(3)$ & $3.389(5)$ & $126(2)$ \\
\hline $\mathrm{C} 12 \mathrm{~A}$ & $\mathrm{H} 12 \mathrm{~A}$ & $\mathrm{O}_{1} \mathrm{~A}^{1}$ & $0.97(3)$ & $2.35(3)$ & $3.132(4)$ & $137(3)$ \\
\hline $\mathrm{O} 2 \mathrm{~B}$ & $\mathrm{H} 2 \mathrm{~B}$ & $\mathrm{O}_{1 \mathrm{~B}}{ }^{4}$ & $0.90(5)$ & $1.96(5)$ & $2.814(3)$ & $159(4)$ \\
\hline $\mathrm{O} 2 \mathrm{~B}$ & $\mathrm{H} 2 \mathrm{~B}$ & $\mathrm{~N}_{2} \mathrm{~B}^{4}$ & $0.90(5)$ & $2.31(5)$ & $2.913(3)$ & $124(4)$ \\
\hline N1B & H1B & $\mathrm{O} 2 \mathrm{~B}^{5}$ & $0.88(4)$ & $2.25(4)$ & $3.103(4)$ & $163(4)$ \\
\hline C6B & H6B & $\mathrm{N}_{1} \mathrm{~A}^{6}$ & $0.99(3)$ & 2.67(4) & $3.419(5)$ & 133(3) \\
\hline $\mathrm{C} 12 \mathrm{~B}$ & $\mathrm{H} 12 \mathrm{~B}$ & $\mathrm{O}_{1 B}{ }^{4}$ & $0.94(3)$ & $2.47(4)$ & $3.179(4)$ & $132(3)$ \\
\hline
\end{tabular}

${ }^{1} 1 / 2+X, 3 / 2-Y,+Z ;{ }^{2}-1 / 2+X, 3 / 2-Y,+Z ;{ }^{3} 3 / 2-X,-1 / 2+Y,-1 / 2+Z ;{ }^{4}-1 / 2+X, 1 / 2-Y,+Z ;{ }^{5} 1 / 2+X, 1 / 2-Y,+Z ;{ }^{6} 1-X, 1-Y, 1 / 2+Z$

A Hirshfeld surface analysis was conducted to verify the contributions of the different intermolecular interactions. This analysis was used to investigate the presence of hydrogen bonds and other weak intermolecular interactions in the crystal structure. The Hirshfeld surface analysis ${ }^{34}$ was generated by CrystalExplorer $17.5^{35}$ and comprised $d_{\text {norm }}$ surface plots and 2D (twodimensional) fingerprint plots ${ }^{36}$. The plots of the Hirshfeld surface confirms the presence of the non-covalent interaction described below (Figure 3), taking account that in the asymmetrical unit there are two units (A and B) a procedure described previously in the literature was used to a better analysis and understanding of this interactions ${ }^{37}$. As described above, a strong hydrogen bonding interaction is observed in the crystal structure generating a 2D-network in the crystal structure, where units " $\mathrm{A}$ " and "B" are interacting with $\mathrm{N}-\mathrm{H} \cdots \mathrm{O}$ hydrogen bond interaction, despite of both units are in different planes of the crystal, according to the symmetry elements on it. This are depicted in the Figure 3 , where the both units are well defined and are interacting between them. 

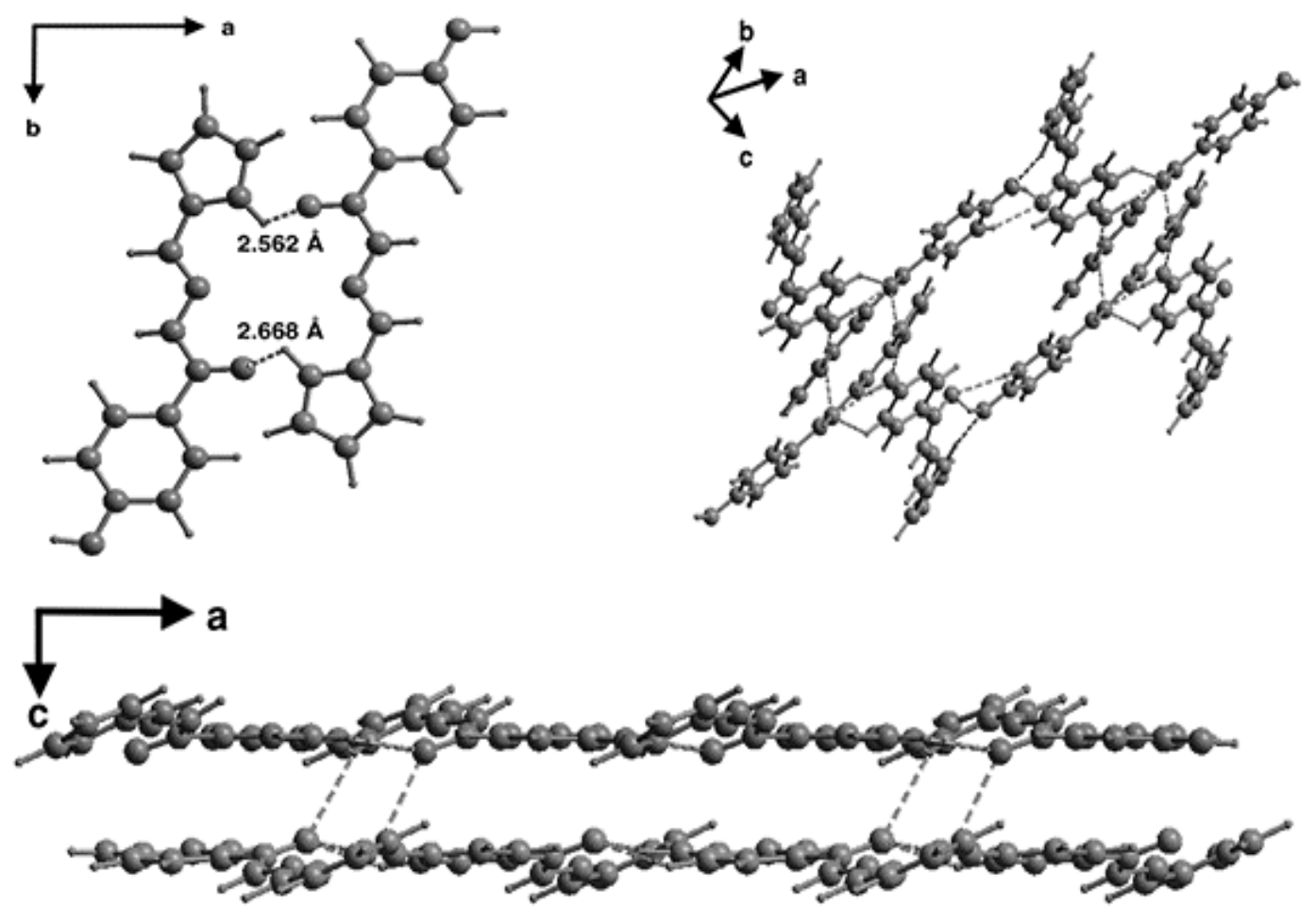

Figure 3. 2-D network generated for the title compound. Units A and B are defined by red and blue colours respectively.

In order to visualize and quantify the similarities and differences in intermolecular contacts across the crystal structure the Hirshfeld surface analysis was made for the molecules A and B present in the asymmetric unit independently (see Figure 4.).
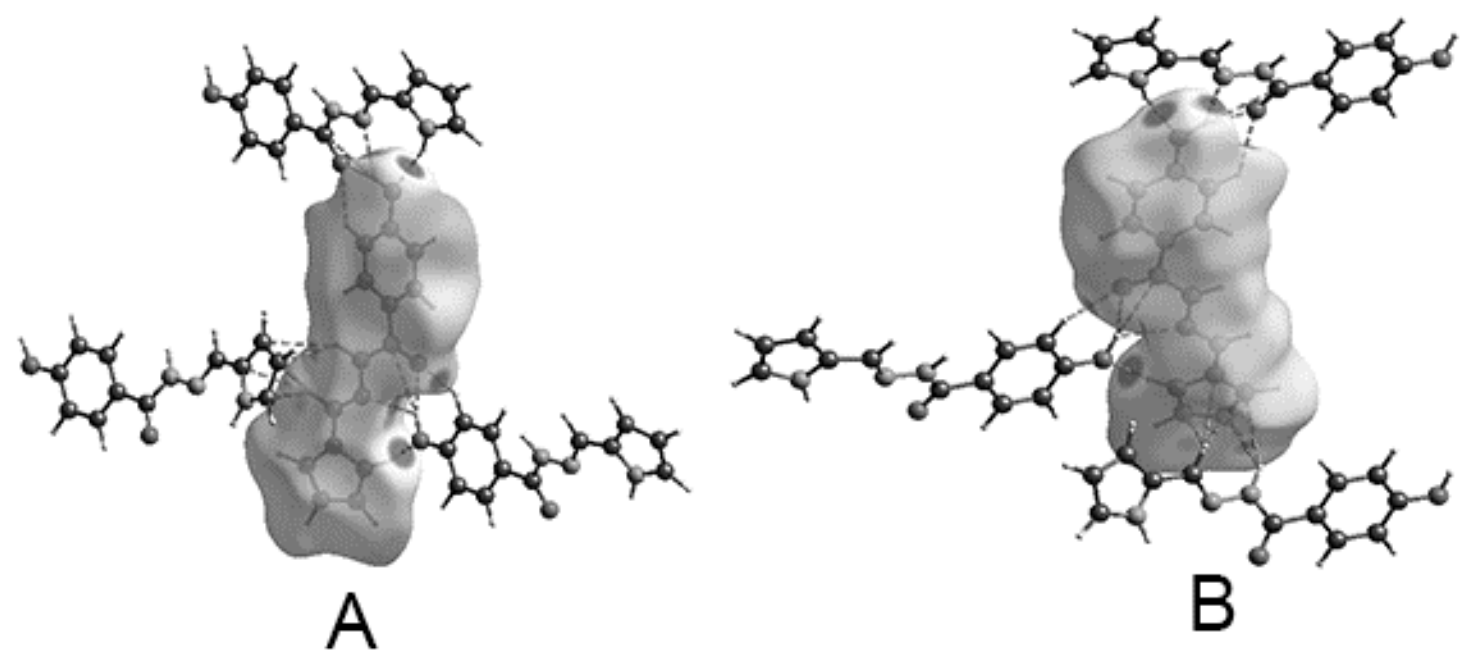

$$
\begin{aligned}
& \mathrm{H} \cdots \mathrm{O} \\
& \mathrm{H} \cdots \mathrm{N} \\
& \mathrm{H} \cdots \mathrm{C}
\end{aligned}
$$

Figure 4. Hirshfeld surface of the title compound for each unit.

The weak intermolecular interactions are mainly constituted by $\mathrm{H} \cdots \mathrm{O}, \mathrm{H} \cdots \mathrm{N}$ and $\mathrm{H} \cdots \mathrm{C}$, the contribution for both units are depicted in Figure 5. Where the reciprocal contacts appear as a sharp wing for $\mathrm{H} \cdots \mathrm{O}$, with $d_{\mathrm{e}}+d_{\mathrm{i}} \simeq 1.8 \AA$, for $\mathrm{H} \cdots \mathrm{N}$ as a diffuse wing with $d_{\mathrm{e}}+d_{\mathrm{i}} \simeq 2.1 \AA$ and, $\mathrm{H} \cdots \mathrm{C}$ as asymmetrical wings with $d_{\mathrm{e}}+d_{\mathrm{i}} \simeq 2.9$ $\AA$. In general, both units show a similar fingerprint plots except the $\mathrm{H} \cdots \mathrm{C}$ interaction. We can assume that this difference in the plot could be due to chirality of the crystal structure (non-centrosymmetric setting) or the antiparallel direction generated by the interactions in the both units. 

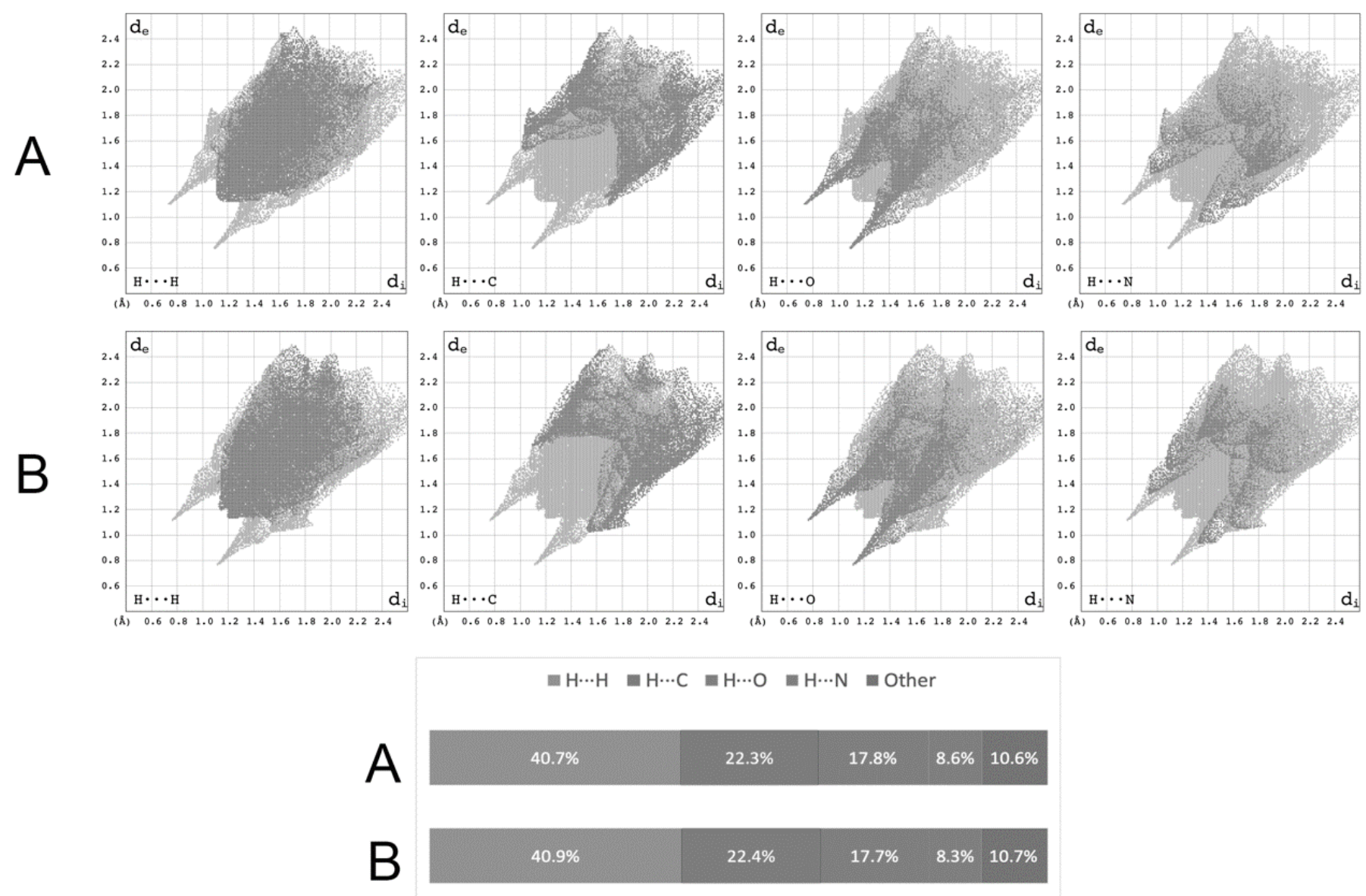

Figure 5. Fingerprint plots for units A and B (top) and weak interactions contributions (bottom).

Finally, energy framework was analysed to a better understanding of the packing of crystal structure and the supramolecular rearrangement. According to the tube direction, it can conclude that the formation of the framework is directed by the translational symmetry elements in each unit a long of $a-$ axis due the strong hydrogen bond interaction $\mathrm{O}-\mathrm{H} \cdots \mathrm{O}$ and $\mathrm{N}-\mathrm{H} \cdots \mathrm{O}$ type directing the crystal structure layer by layer in the (110) plane disposing the molecular structure in an antiparallel zig-zag setting, according to the electrostatic $\left(\mathrm{E}_{\mathrm{ele}}\right)$. The dispersion $\left(\mathrm{E}_{\mathrm{dis}}\right)$ energy shows a hexagonal cage as a component of the framework energy being less dominating than $\left(\mathrm{E}_{\text {ele }}\right.$ ) (see Figure 6). This rearrangement allows the formation of another weak interactions in the crystal structure such as $\mathrm{H} \cdots \pi$ between the pyrrole ring and the $\mathrm{H}-\mathrm{CNN}-\mathrm{H}$ fragment. To the best of our knowledge already exists little examples of $\mathrm{H} \cdots \pi$ weaks interactions between hydrogen and heterocycles ${ }^{38,39}$.

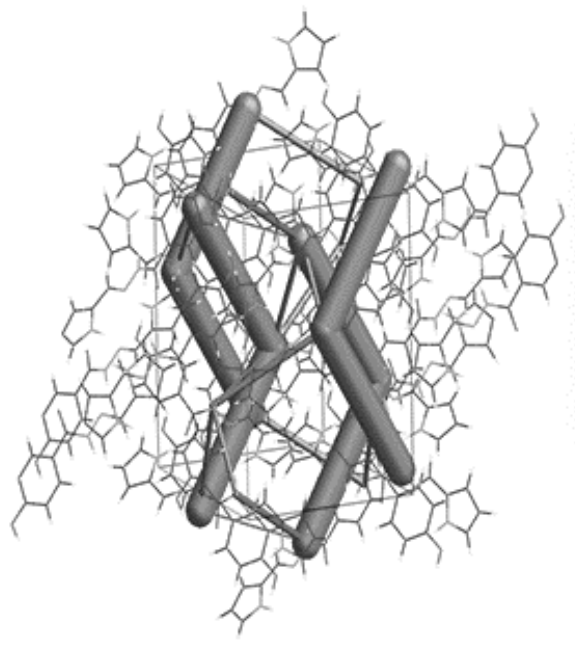

Electrostatic

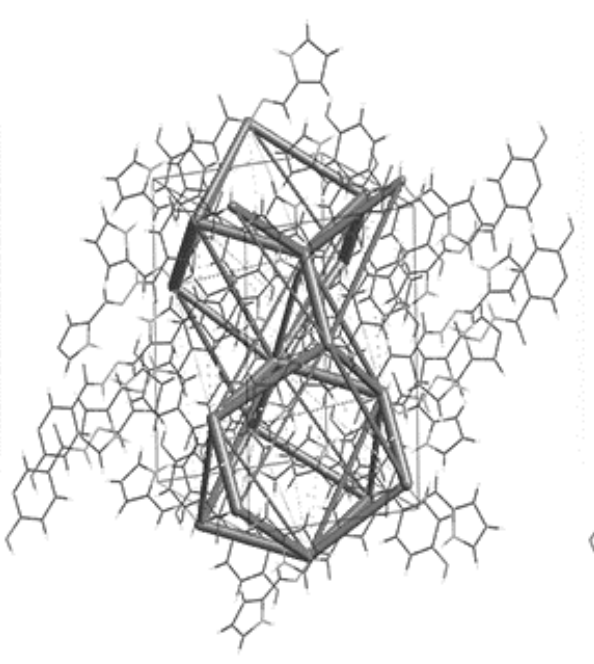

Dispersion

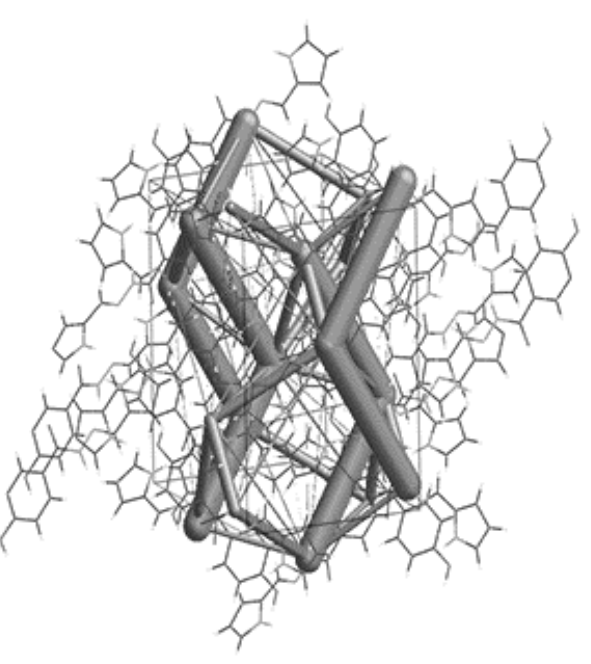

Total

Figure 6. Energy framework diagrams for $\left(\mathrm{E}_{\mathrm{ele}}\right),\left(\mathrm{E}_{\mathrm{dis}}\right)$ and $\left(\mathrm{E}_{\mathrm{tot}}\right)$ for title compound. 


\section{CONCLUSIONS}

In this study we offer the report of structural studies of the title compound, showing the $E$ isomer in the solid state. The weak intermolecular interactions show a 2D supramolecular network. Both molecules are essentially overlaid between them with RMSD $=0.0574$; $\max \mathrm{D}=0.1211 \AA$ considering inversion and flexibility. The understanding of the crystal packing of this molecule allows to postulate this compound in some applications such as synthesis, catalysis, crystal engineering, pharmaceutical design, molecular biology, molecular recognition, materials.

\section{ACKNOWLEDGEMENTS}

Iván Brito, Alejandro Cárdenas and Jonathan Cisterna, thank to Universidad de Antofagasta for purchase license for the Cambridge Structural Database and for the financial support. Jonathan Cisterna acknowledge to Universidad de Antofagasta for postdoctoral fellowship.

\section{REFERENCES}

1. G. Cavallo, P. Metrangolo, R. Milani, T. Pilati, A. Priimagi, G. Resnati and G. Terraneo, Chem. Rev., 2016, 116, 2478-2601.

2. E. A. Kvyatkovskaya, V. P. Zaytsev, F. I. Zubkov, P. V. Dorovatovskii, Y. V. Zubavichus and V. N. Khrustalev, Acta Crystallogr. Sect. E Crystallogr. Commun., 2017, 73, 515-519.

3. K. T. Mahmudov, M. N. Kopylovich, M. F. C. Guedes Da Silva and A. J. L. Pombeiro, Dalt. Trans., 2017, 46, 10121-10138.

4. S. Scheiner, Acc. Chem. Res., 2013, 46, 280-288.

5. R. Jlassi, A. P. C. Ribeiro, M. F. C. Guedes Da Silva, K. T. Mahmudov, M. N. Kopylovich, T. B. Anisimova, H. Naili, G. A. O. Tiago and A. J. L. Pombeiro, Eur. J. Inorg. Chem., 2014, 2014, 4541-4550.

6. P. Politzer, J. S. Murray, T. Clark and G. Resnati, Phys. Chem. Chem. Phys., 2017, 19, 32166-32178.

7. F. I. Zubkov, D. F. Mertsalov, V. P. Zaytsev, A. V. Varlamov, A. V. Gurbanov, P. V. Dorovatovskii, T. V. Timofeeva, V. N. Khrustalev and K. T. Mahmudov, J. Mol. Liq., 2018, 249, 949-952.

8. N. Q. Shikhaliyev, N. E. Ahmadova, A. V. Gurbanov, A. M. Maharramov, G. Z. Mammadova, V. G. Nenajdenko, F. I. Zubkov, K. T. Mahmudov and A. J. L. Pombeiro, Dye. Pigment., 2018, 150, 377-381.

9. D. K. Nasirova, A. V. Malkova, K. B. Polyanskii, K. Y. Yankina, P. N. A. Amoyaw, I. A. Kolesnik, A. V. Kletskov, I. A. Godovikov, E. V. Nikitina and F. I. Zubkov, Tetrahedron Lett., 2017, 58, 4384-4387.

10. D. Y. Vandyshev, K. S. Shikhaliev, A. Y. Potapov, M. Y. Krysin, F. I. Zubkov and L. V. Sapronova, Beilstein J. Org. Chem., 2017, 13, 2561-2568.

11. A. A. Shetnev and F. I. Zubkov, Chem. Heterocycl. Compd., 2017, 53, 495497.

12. G. R. Desiraju, Angew. Chemie Int. Ed. English, 1995, 34, 2311-2327.

13. K. T. Mahmudov and A. J. L. Pombeiro, Chem. - A Eur. J., 22, 1635616398.

14. K. T. Mahmudov, M. N. Kopylovich, A. Sabbatini, M. G. B. Drew, M. D. R. S. Martins, C. Pettinari and A. J. L. Pombeiro, Inorg. Chem., 2014, 53, 9946-9958.

15. A. V. Gurbanov, G. Mahmoudi, M. F. C. Guedes da Silva, F. I. Zubkov, K. T. Mahmudov and A. J. L. Pombeiro, Inorganica Chim. Acta, 2018, 471, $130-136$.

16. K. T. Mahmudov, M. N. Kopylovich, M. F. C. Guedes da Silva and A. J. L. Pombeiro, Coord. Chem. Rev., 2017, 345, 54-72.

17. S. Hazra, N. M. R. Martins, K. Mahmudov, F. I. Zubkov, M. F. C. Guedes da Silva and A. J. L. Pombeiro, J. Organomet. Chem., 2018, 867, 193-200.

18. G. Mahmoudi, E. Zangrando, M. P. Mitoraj, A. V. Gurbanov, F. I. Zubkov, M. Moosavifar, I. A. Konyaeva, A. M. Kirillov and D. A. Safin, New J. Chem., 2018, 42, 4959-4971.

19. A. V. Gurbanov, K. T. Mahmudov, M. N. Kopylovich, F. M. Guedes da Silva, M. Sutradhar, F. I. Guseinov, F. I. Zubkov, A. M. Maharramov and A. J. L. Pombeiro, Dye. Pigment., 2017, 138, 107-111.

20. G. Mahmoudi, F. A. Afkhami, H. S. Jena, P. Nematollahi, M. D. Esrafili, P. Garczarek, K. Van Hecke, M. Servati Gargari and A. M. Kirillov, New J. Chem., 2016, 40, 10116-10126.

21. A. A. Khandar, B. K. Ghosh, C. Lampropoulos, M. S. Gargari, V. T. Yilmaz, K. Bhar, S. A. Hosseini-Yazdi, J. M. Cain and G. Mahmoudi, Polyhedron, 2015, 85, 467-475.

22. Bruker AXS INC., APEX3, SAINT and SADABS, 2016, Bruker AXS Inc., Madison, Wisconsin, USA.

23. G. M. Sheldrick, Acta Crystallogr. Sect. C Struct. Chem., 2015, 71, 3-8.
24. O. V Dolomanov, L. J. Bourhis, R. J. Gildea, J. A. K. Howard and H. Puschmann, J. Appl. Crystallogr., 2009, 42, 339-341.

25. S. C. Abrahams and E. T. Keve, Acta Crystallogr. Sect. A, 1971, 27, 157165.

26. C. D. Centre and L. Road, 1986, 13, 4343-4348.

27. F. H. Allen, O. Kennard, D. G. Watson, L. Brammer and A. G. Orpen, 1987, $1-19$.

28. X. P. Ye, T. F. Zhu, W. N. Wu, T. L. Ma, J. Xu, Z. P. Zhang, Y. Wang and L. Jia, Inorg. Chem. Commun., 2014, 47, 60-62.

29. P. D. Mao, L. L. Yan, W. N. Wu and H. X. Cai, Zeitschrift fur Krist. - New Cryst. Struct., 2017, 232, 899-900.

30. C. R. Groom, I. J. Bruno, M. P. Lightfoot and S. C. Ward, Acta Crystallogr. Sect. B Struct. Sci. Cryst. Eng. Mater., 2016, 72, 171-179.

31. S. C. Abrahams and E. T. Keve, Acta Crystallogr. Sect. A, 1971, 27, 157165.

32. A. L. Spek, J. Appl. Crystallogr., 2003, 36, 7-13.

33. J. Bernstein, R. E. Davis, L. Shimoni and N. -L Chang, Angew. Chemie Int. Ed. English, 1995, 34, 1555-1573.

34. J. J. McKinnon, D. Jayatilaka and M. A. Spackman, Chem. Commun., 2007, 3814-3816.

35. M. A. Wolff, S.K., Grimwood, D.J., McKinnon, J.J., Turner, M.J., Jayatilaka, D. and Spackman, 2012, Crystal Explorer 17.5. University of Western Austr.

36. M. A. Spackman and J. J. McKinnon, CrystEngComm, 2002, 4, 378-392.

37. K. K. Jha, S. Dutta, V. Kumar and P. Munshi, CrystEngComm, 2016, 18, 8497-8505.

38. I. Rozas, I. Alkorta and J. Elguero, J. Phys. Chem. A, 1997, 101, 9457-9463.

39. S. M. M. Sony and M. N. Ponnuswamy, Cryst. Growth Des., 2006, 6, 736742. 